\title{
Climate on tundra and thoughts on causes of regional climate differences
}

\author{
Atsumu Ohmura \\ Institute for Climate Research, Swiss Federal Institute of Technology, Winterthurerstrasse 190, CH-8057 Zürich, Switzerland
}

\begin{abstract}
The Axel Heiberg Island Expedition of McGill University, Montréal, Canada, led by the late Fritz Müller was the cradle for a number of scientific investigations, not all of them glaciological. During the four years 1969-72, the tundra climate was investigated in the Expedition Area, encompassing about $100 \mathrm{~km}^{2}$ on the mid-west coast of Axel Heiberg Island, Nunavut, Canada. This series of studies identified the main features of the tundra climate, clarified its causal processes and contributed to an understanding of the differences between tundra climates and those of the neighboring regions with glaciers, ocean surfaces and boreal forests. A fundamental consideration of climate processes on a global scale was conceived during this time. Some significant results are recorded here to commemorate Fritz Müller's contributions as a polar scientist and a university educator.
\end{abstract}

\section{INTRODUGTION}

The tundra covers $7.2 \times 10^{6} \mathrm{~km}^{2}$, or $4.8 \%$ of the entire land surface of the Earth. Within the Arctic Circle, however, the tundra surface occupies $20 \%$ of the entire surface, and is the second largest surface after the ocean. Being located between the ice-filled ocean and the glaciers, the tundra region shows a distinctively mild climate during the short snow-free season in summer when the terrestrial ecology is most active. Apart from the atmospheric conditions, the summer climate of the tundra region is strongly affected by the snow-cover depth which influences the onset of the snow-free season. After the snow cover disappears, the tundra exhibits a distinctive heat-balance regime which makes the summer climate of this region so different from that of the Arctic Ocean or glaciers. The base camp of the Axel Heiberg Island Expedition of McGill University, Montréal, Canada, became the first site of a continuous investigation of microclimate and heat balance on the tundra, which is sufficiently long to be called climatological. In this paper, the main features of the tundra climate, its heat balance and the physical processes of the heat balance that create the tundra climate are presented.

\section{TUNDRA CLIMATE}

Before the onset of melt, the regional climate difference in the Arctic is small and influenced weakly by the surface characteristics (Table 1), because of the homogeneity of the surface in this season. Regardless of whether the surface is ocean, tundra or glacier, the Arctic surface is covered by the dry-snow cover which has fairly consistent thermal and radiative characteristics. During the dry-snow season, usually before June, the air-temperature distribution is influenced mainly by the surface roughness and the altitude.

*Contribution to the Fritz Müller Memorial, Zürich, 1999.
The regional differences driven by the differences in the radiative and thermal characteristics become significant only during the melt period. The melt period on the Arctic tundra is usually brief owing to the limited water equivalent of the snow cover. The year's highest monthly mean temperature on the tundra appears soon after the melt period, and is $2-4^{\circ} \mathrm{C}$ warmer than over ocean or glacier surfaces.

In addition to higher mean air temperature, the tundra climate in summer is characterized by a larger daily temperature range (daily maximum minus minimum). The daily temperature range consists of the amplitude of the diurnal periodicity $(24 \mathrm{~h}$ ) and the aperiodic component (daily range minus diurnal amplitude). The former is created by the $24 \mathrm{~h}$ period in the solar elevation, and the latter by advection and convection. Prior to March, the solar elevation is small, and the aperiodic change dominates the daily range. In this season there is a slight regional variation in the daily temperature variation which is largest on the tundra. This type of temperature change is associated with the wind speed which is a good indicator of the vertical mixing of the boundary layer. Since the vertical temperature difference in the stable boundary layer is large, the temperature variability caused by vertical mixing is more significant than the temperature change due to the horizontal advection of different air masses for a short period such as a day. Given the same wind speed, the vertical mixing is usually more intense over the tundra than over the oceans and glaciers, due to the tundra's rough surface and topography. After the year's maximum daily range and diurnal amplitude are observed in April, the daily temperature range becomes small in high summer throughout the Arctic. This seasonal phenomenon is called a Fram-type temperature change (Simpson, 1919). Even during this season, however, the daily range remains higher in the interior tundra than at the coastal and oceanic sites. The daily maximum temperature on the tundra can be as much as $5-10^{\circ} \mathrm{C}$ higher than at ocean and glacier sites. The daily minimum temperature is $1-4^{\circ} \mathrm{C}$ warmer on the tundra than over oceans and glaciers at the same altitudes. 


\begin{tabular}{|c|c|c|c|c|c|c|c|}
\hline & & April & May & June & fuly & August & Reference period \\
\hline \multicolumn{8}{|l|}{ Interior tundra } \\
\hline Britannia Sø & $\begin{array}{l}\text { Mean } \\
\text { Daily range } \\
\text { Diurnal amplitude } \\
\text { Aperiodic change }\end{array}$ & $\begin{array}{r}-10.5 \\
7.2 \\
3.2 \\
4.0\end{array}$ & $\begin{array}{r}-2.5 \\
7.4 \\
4.2 \\
3.2\end{array}$ & $\begin{array}{l}5.8 \\
7.4 \\
2.7 \\
4.7 \\
4\end{array}$ & $\begin{array}{l}7.1 \\
7.7 \\
3.0 \\
4.7 \\
4\end{array}$ & $\begin{array}{l}6.0 \\
6.1 \\
3.0 \\
3.1 \\
\end{array}$ & $1953-54$ \\
\hline Hazen Camp & $\begin{array}{l}\text { Mean } \\
\text { Daily range } \\
\text { Diurnal amplitude } \\
\text { Aperiodic change }\end{array}$ & $\begin{array}{r}-32.3 \\
12.5 \\
4.1 \\
8.4\end{array}$ & $\begin{array}{r}-12.8 \\
7.8 \\
3.5 \\
4.4\end{array}$ & $\begin{array}{l}2.4 \\
6.2 \\
2.8 \\
3.4\end{array}$ & $\begin{array}{l}6.1 \\
7.0 \\
2.6 \\
4.4\end{array}$ & $\begin{array}{l}\mathrm{m} \\
\mathrm{m} \\
2.7 \\
\mathrm{~m}\end{array}$ & $1958,62,64-66$ \\
\hline Bace Camp, Axel Heiberg Island & $\begin{array}{l}\text { Mean } \\
\text { Daily range } \\
\text { Diurnal amplitude } \\
\text { Aperiodic change }\end{array}$ & $\begin{array}{c}\mathrm{m} \\
8.7 \\
5.2 \\
3.5\end{array}$ & $\begin{array}{r}-8.7 \\
7.6 \\
3.5 \\
4.1\end{array}$ & $\begin{array}{l}2.1 \\
5.4 \\
1.6 \\
3.9\end{array}$ & $\begin{array}{l}6.2 \\
6.0 \\
2.1 \\
3.9\end{array}$ & $\begin{array}{l}4.1 \\
5.5 \\
2.6 \\
2.9\end{array}$ & $1951-60$ \\
\hline Ermine Ridge, Axel Heiberg Island & $\begin{array}{l}\text { Mean } \\
\text { Daily range } \\
\text { Diurnal amplitude } \\
\text { Aperiodic change }\end{array}$ & $\begin{array}{l}\mathrm{m} \\
\mathrm{m} \\
\mathrm{m} \\
\mathrm{m}\end{array}$ & $\begin{array}{r}-9.1 \\
8.7 \\
4.4 \\
4.3\end{array}$ & $\begin{array}{r}-1.1 \\
6.6 \\
3.8 \\
2.8\end{array}$ & $\begin{array}{l}1.6 \\
5.0 \\
1.8 \\
3.2\end{array}$ & $\begin{array}{l}2.4 \\
4.3 \\
2.2 \\
2.1\end{array}$ & $1969-72$ \\
\hline \multicolumn{8}{|l|}{ Coastal tundra } \\
\hline Alert & $\begin{array}{l}\text { Mean } \\
\text { Daily range } \\
\text { Diurnal amplitude } \\
\text { Aperiodic change }\end{array}$ & $\begin{array}{r}-23.9 \\
8.5 \\
2.0 \\
6.5\end{array}$ & $\begin{array}{r}-11.3 \\
6.6 \\
2.2 \\
4.4\end{array}$ & $\begin{array}{r}-0.1 \\
5.0 \\
1.1 \\
3.9\end{array}$ & $\begin{array}{l}3.9 \\
6.3 \\
1.1 \\
5.2\end{array}$ & $\begin{array}{l}0.8 \\
4.7 \\
1.5 \\
3.2\end{array}$ & $1951-60$ \\
\hline Eureka & $\begin{array}{l}\text { Mean } \\
\text { Daily range } \\
\text { Diurnal amplitude } \\
\text { Aperiodic change }\end{array}$ & $\begin{array}{r}-26.8 \\
8.9 \\
4.6 \\
4.3\end{array}$ & $\begin{array}{r}-9.7 \\
7.0 \\
3.9 \\
3.1\end{array}$ & $\begin{array}{l}2.7 \\
5.3 \\
2.4 \\
2.9\end{array}$ & $\begin{array}{l}5.7 \\
6.1 \\
2.1 \\
4.0\end{array}$ & $\begin{array}{l}3.8 \\
4.9 \\
1.7 \\
3.2\end{array}$ & $1951-60$ \\
\hline Isachsen & $\begin{array}{l}\text { Mean } \\
\text { Daily range } \\
\text { Diurnal amplitude } \\
\text { Aperiodic change }\end{array}$ & $\begin{array}{r}-24.2 \\
7.6 \\
3.3 \\
4.3\end{array}$ & $\begin{array}{r}-11.5 \\
6.2 \\
2.6 \\
3.6\end{array}$ & $\begin{array}{r}-0.2 \\
4.3 \\
2.3 \\
2.0\end{array}$ & $\begin{array}{l}3.7 \\
4.9 \\
2.3 \\
2.6\end{array}$ & $\begin{array}{l}1.4 \\
4.5 \\
1.9 \\
2.6\end{array}$ & $1951-60$ \\
\hline Mould Bay & $\begin{array}{l}\text { Mean } \\
\text { Daily range } \\
\text { Diurnal amplitude } \\
\text { Aperiodic change }\end{array}$ & $\begin{array}{r}-22.7 \\
8.5 \\
4.9 \\
3.6\end{array}$ & $\begin{array}{r}-10.8 \\
6.0 \\
3.4 \\
2.6\end{array}$ & $\begin{array}{l}0.2 \\
4.5 \\
2.2 \\
2.3\end{array}$ & $\begin{array}{l}4.0 \\
5.1 \\
2.6 \\
2.5\end{array}$ & $\begin{array}{l}1.8 \\
4.3 \\
1.7 \\
2.6\end{array}$ & $1951-60$ \\
\hline Resolute & $\begin{array}{l}\text { Mean } \\
\text { Daily range } \\
\text { Diurnal amplitude } \\
\text { Aperiodic change }\end{array}$ & $\begin{array}{r}-22.1 \\
8.1 \\
3.4 \\
4.7\end{array}$ & $\begin{array}{r}-10.2 \\
6.1 \\
3.3 \\
2.8\end{array}$ & $\begin{array}{l}0.6 \\
4.7 \\
2.1 \\
2.6\end{array}$ & $\begin{array}{l}4.6 \\
5.5 \\
2.4 \\
3.1\end{array}$ & $\begin{array}{l}2.9 \\
4.5 \\
2.2 \\
2.3\end{array}$ & $1951-60$ \\
\hline Nord & $\begin{array}{l}\text { Mean } \\
\text { Daily range } \\
\text { Diurnal amplitude } \\
\text { Aperiodic change }\end{array}$ & $\begin{array}{r}-24.0 \\
8.1 \\
2.3 \\
5.8\end{array}$ & $\begin{array}{r}-11.2 \\
6.8 \\
2.5 \\
4.3\end{array}$ & $\begin{array}{r}-0.4 \\
5.1 \\
1.6 \\
3.5\end{array}$ & $\begin{array}{l}3.9 \\
6.0 \\
1.5 \\
4.5\end{array}$ & $\begin{array}{l}1.4 \\
5.0 \\
1.8 \\
3.2 \\
\end{array}$ & $1951-60$ \\
\hline Glacier (ablation area) & & & & & & & \\
\hline Lower Ice, Axel Heiberg Island & $\begin{array}{l}\text { Mean } \\
\text { Daily range } \\
\text { Diurnal amplitude } \\
\text { Aperiodic change }\end{array}$ & $\begin{array}{l}\mathrm{m} \\
\mathrm{m} \\
\mathrm{m} \\
\mathrm{m}\end{array}$ & $\begin{array}{r}-8.7 \\
7.2 \\
3.2 \\
4.0\end{array}$ & $\begin{array}{l}1.4 \\
5.2 \\
1.4 \\
3.8\end{array}$ & $\begin{array}{l}4.5 \\
4.9 \\
1.2 \\
3.7\end{array}$ & $\begin{array}{l}3.2 \\
4.6 \\
1.0 \\
3.6\end{array}$ & $1951-60$ \\
\hline $\begin{array}{l}\text { Anniversary Profile, Axel } \\
\text { Heiberg Island }\end{array}$ & $\begin{array}{l}\text { Mean } \\
\text { Daily range } \\
\text { Diurnal amplitude } \\
\text { Aperiodic change }\end{array}$ & $\begin{array}{l}\mathrm{m} \\
\mathrm{m} \\
\mathrm{m} \\
\mathrm{m}\end{array}$ & $\begin{array}{r}-10.5 \\
6.5 \\
3.4 \\
3.1\end{array}$ & $\begin{array}{r}-2.5 \\
4.6 \\
2.0 \\
2.6\end{array}$ & $\begin{array}{l}1.5 \\
3.4 \\
1.1 \\
2.3\end{array}$ & $\begin{array}{l}1.8 \\
2.8 \\
1.8 \\
1.0\end{array}$ & $1969-72$ \\
\hline $\begin{array}{l}\text { Moraine Profile, Axel } \\
\text { Heiberg Island }\end{array}$ & $\begin{array}{l}\text { Mean } \\
\text { Daily range } \\
\text { Diurnal amplitude } \\
\text { Aperiodic change }\end{array}$ & $\begin{array}{l}\mathrm{m} \\
\mathrm{m} \\
\mathrm{m} \\
\mathrm{m}\end{array}$ & $\begin{array}{r}-10.2 \\
9.3 \\
3.8 \\
5.5\end{array}$ & $\begin{array}{r}-3.9 \\
9.2 \\
6.0 \\
3.2\end{array}$ & $\begin{array}{r}-0.2 \\
6.8 \\
2.3 \\
4.5\end{array}$ & $\begin{array}{r}-0.7 \\
6.3 \\
3.6 \\
2.7\end{array}$ & $1969-72$ \\
\hline Glacier (accumulation area) & & & & & & & \\
\hline Upper Ice II, Axel Heiberg Island & $\begin{array}{l}\text { Mean } \\
\text { Daily range } \\
\text { Diurnal amplitude } \\
\text { Aperiodic change }\end{array}$ & $\begin{array}{l}\mathrm{m} \\
\mathrm{m} \\
\mathrm{m} \\
\mathrm{m}\end{array}$ & $\begin{array}{l}\mathrm{m} \\
8.9 \\
2.2 \\
6.7\end{array}$ & $\begin{array}{r}-9.4 \\
6.2 \\
2.1 \\
4.1\end{array}$ & $\begin{array}{r}-5.2 \\
4.8 \\
1.3 \\
3.5\end{array}$ & $\begin{array}{r}-6.3 \\
5.0 \\
1.9 \\
3.1\end{array}$ & 1961 \\
\hline
\end{tabular}


Table 1. Monthly statistics of air temperature for various surfaces (cont'd)

\begin{tabular}{|c|c|c|c|c|c|c|c|}
\hline & & April & May & fune & fuly & August & Reference per \\
\hline \multicolumn{8}{|l|}{ Glacier (accumulation area) } \\
\hline North Ice & $\begin{array}{l}\text { Mean } \\
\text { Daily range } \\
\text { Diurnal amplitude } \\
\text { Aperiodic change }\end{array}$ & $\begin{array}{r}-33.9 \\
10.0 \\
6.5 \\
3.5\end{array}$ & $\begin{array}{r}-23.2 \\
10.3 \\
8.2 \\
2.1\end{array}$ & $\begin{array}{r}-14.1 \\
8.8 \\
6.8 \\
2.0\end{array}$ & $\begin{array}{r}-12.4 \\
7.2 \\
5.4 \\
1.8\end{array}$ & $\begin{array}{r}-14.1 \\
7.5 \\
4.9 \\
2.6\end{array}$ & $1951-60$ \\
\hline Eismitte and Station Central & $\begin{array}{l}\text { Mean } \\
\text { Daily range } \\
\text { Diurnal amplitude } \\
\text { Aperiodic change }\end{array}$ & $\begin{array}{r}-34.1 \\
14.0 \\
8.5 \\
5.5\end{array}$ & $\begin{array}{r}-19.2 \\
14.5 \\
10.5 \\
4.0\end{array}$ & $\begin{array}{r}-13.8 \\
12.8 \\
9.8 \\
3.0\end{array}$ & $\begin{array}{r}-12.4 \\
10.6 \\
7.8 \\
2.8\end{array}$ & $\begin{array}{r}-15.9 \\
12.7 \\
8.4 \\
4.3\end{array}$ & $1951-60$ \\
\hline \multicolumn{8}{|l|}{ Ocean } \\
\hline Maud in pack ice & $\begin{array}{l}\text { Mean } \\
\text { Daily range } \\
\text { Diurnal amplitude } \\
\text { Aperiodic change }\end{array}$ & $\begin{array}{r}-21.9 \\
5.6 \\
4.0 \\
1.6\end{array}$ & $\begin{array}{r}-12.2 \\
4.0 \\
2.4 \\
1.6\end{array}$ & $\begin{array}{r}-1.7 \\
2.7 \\
1.3 \\
1.4\end{array}$ & $\begin{array}{r}-0.1 \\
2.1 \\
1.0 \\
1.1\end{array}$ & $\begin{array}{l}0.1 \\
1.5 \\
0.9 \\
0.6\end{array}$ & $1923-24$ \\
\hline Fram in pack ice & $\begin{array}{l}\text { Mean } \\
\text { Daily range } \\
\text { Diurnal amplitude } \\
\text { Aperiodic change }\end{array}$ & $\begin{array}{r}-22.8 \\
7.3 \\
3.3 \\
4.0\end{array}$ & $\begin{array}{r}-11.0 \\
5.1 \\
1.7 \\
3.4\end{array}$ & $\begin{array}{r}-1.8 \\
3.5 \\
1.3 \\
2.2\end{array}$ & $\begin{array}{l}0.1 \\
2.1 \\
0.7 \\
1.4\end{array}$ & $\begin{array}{r}-1.8 \\
3.6 \\
1.1 \\
2.5\end{array}$ & $1894-96$ \\
\hline
\end{tabular}

Note: The sources are as follows: Britannia Sø (Hamilton and Rollitt, 1957a), Hazen Camp (Jackson, 1959a,b), Axel Heiberg Island (Ohmura, 1981), Ermine Ridge (Ohmura and Müller, 1977), Alert, Eureka, Isachsen, Mould Bay and Resolute (Thompson, 1967), Nord (WMO, 1971), Upper Ice II (Müller and Roskin-Sharlin, 1967), North Ice (Hamilton and Rollitt, 1957b), Eismitte and Station Central (Loewe, 1935; Ratzki, 1960), Maud (Sverdrup, 1933), Fram (Nansen, 1905). m, missing data.

The larger daily range for the tundra region in summer is due to the larger diurnal amplitude rather than the aperiodic component. From detailed investigations of the mesoscale temperature distribution on Axel Heiberg Island (Ohmura and Müller 1977), it was deduced that the major transition between the oceanic and tundra climate takes place within $1-2 \mathrm{~km}$ of the coastal zones. Almost all meteorological stations in the Canadian Arctic and Greenland are located in this narrow coastal strip. If the modelcomputed characteristics of temperature for the land surfaces in the Arctic are to be validated by meteorological observations, the latter should be viewed with caution. They represent a very special temperature condition which prevails only in this coastal zone and are not necessarily representative of the interior tundra climate generally. Of all the stations in this region, Eureka on Ellesmere Island and Søndre Strømfjord on the west coast of Greenland are most representative of the tundra climate.

\section{HEAT BALANGE}

The distinctive nature of the tundra surface emerges during the melt period. During this short period the surface albedo falls from about 0.8 to 0.1 , whereas other lowaltitude Arctic surfaces, such as ocean and the ablation areas of glaciers, retain a relatively high albedo of about 0.5. This sharp decrease in albedo is often considered to cause the regional difference in net radiation which further influences temperature. It is, however, not correct to attempt to explain the regional temperature difference through the difference in net radiation. The distribution of net radiation is fairly homogeneous over ocean, tundra and the glacier ablation areas despite the albedo difference, as is shown for the three summer months JuneAugust in Table 2. The effect of high albedo over the ice surfaces is compensated for by smaller emissions on the melting ice. The regional difference in surface temperature requires consideration of the entire heat-balance process. Further, the heat-balance equation must be viewed from a slightly different standpoint. This equation represents more than the conservation of energy for the Earth's surface; it describes how the Earth's surface reacts upon the imposed energy-flux changes. To arrive at this statement,

Table 2. Energy balance $\left(W^{-2}\right)$ for various surfaces in the Arctic

\begin{tabular}{|c|c|c|c|c|c|c|}
\hline & $\begin{array}{c}\text { Net radiation } \\
R\end{array}$ & $\begin{array}{c}\text { Sensible-heat flux } \\
H\end{array}$ & $\begin{array}{l}\text { Latent-heat flux } \\
\qquad L_{\mathrm{v}} E\end{array}$ & $\begin{array}{c}\text { Subsurface heat flux } \\
G\end{array}$ & $\begin{array}{c}\text { Melt } \\
M\end{array}$ & Source \\
\hline Central Polar Ocean & 73 & -6 & -6 & -6 & -45 & Vowinckel and Orvig (1964) \\
\hline Tundra (Axel Heiberg Island) & 88 & -29 & -40 & -12 & -5 & Ohmura(1982) \\
\hline Glacier, ablation area $\left(\right.$ EGIG $^{*}$ IV $)$ & 91 & 29 & -20 & -11 & -90 & Ambach (1963) \\
\hline Glacier, accumulation area (Upper Ice I) & 20 & 29 & 3 & -10 & -41 & Havens (1964) \\
\hline Boreal forest & 163 & -67 & -78 & -19 & & Pugsley (1970) \\
\hline
\end{tabular}

Note: The value printed between columns $\mathrm{G}$ and $\mathrm{M}$ for boreal forest is the sum of the two fluxes.

* Expédition Glaciologique International au Groenland. 


\begin{tabular}{|c|c|c|c|c|c|c|c|c|c|}
\hline & $\begin{array}{c}\text { Global } \\
\text { radiation } \\
Q+q\end{array}$ & $\begin{array}{l}\text { Reflected } \\
\text { radiation } \\
\qquad r\end{array}$ & $\begin{array}{l}\text { Net shortwave } \\
\text { radiation } \\
Q+q-r\end{array}$ & $\begin{array}{c}\text { Longwave } \\
\text { incoming } \\
\text { radiation } \\
L \downarrow\end{array}$ & $\begin{array}{c}\text { Sensible } \\
\text {-heatflux } \\
H\end{array}$ & $\begin{array}{c}\text { Latent } \\
\text {-heatflux } \\
L_{\mathrm{v}} E\end{array}$ & $\begin{array}{c}\text { Subsurface } \\
\text { heat flux } \\
\text { G }\end{array}$ & $\begin{array}{c}\text { Heat of } \\
\text { fusion } \\
\text { M }\end{array}$ & $\begin{array}{c}\text { Longwave } \\
\text { outgoing } \\
\text { radiation } \\
L \uparrow(\text { eff. } T, K)\end{array}$ \\
\hline Central Polar Ocean & 210 & -105 & 105 & 291 & -6 & -6 & -6 & -55 & $322(275)$ \\
\hline Tundra (Axel Heiberg Island) & 196 & -59 & 137 & 288 & -29 & -40 & -12 & -5 & $339(278)$ \\
\hline Glacier, acc. area (Upper Ice I) & 260 & -205 & 55 & 273 & 29 & 3 & -10 & -41 & $309(272)$ \\
\hline Glacier, acc. area (ETH Camp) & 288 & -223 & 65 & 261 & 16 & -6 & -8 & -30 & $305(271)$ \\
\hline Boreal forest & 230 & -32 & 198 & 358 & -67 & -78 & \multicolumn{2}{|c|}{-19} & $392(288)$ \\
\hline
\end{tabular}

Note: Sources are the same as for Table 2.

the individual terms in the net radiation are expressed in the following energy-balance equation:

$$
(Q+q)(1-a)+L \downarrow-\sigma T^{4}+H+L_{\mathrm{v}} E+G+M=0,
$$

where $Q$ is the direct solar radiation, $q$ is diffuse sky radiation, $a$ is albedo, $L \downarrow$ is longwave incoming radiation, $\sigma$ is the Stefan-Boltzmann constant, $T$ is the surface temperature, $H$ is sensible-heat flux, $L_{\mathrm{v}}$ is latent heat of vaporization, $\mathrm{E}$ is evaporation rate, $G$ is subsurface heat flux and $M$ is the heat of fusion. The sign is defined positive when the flux is directed to the surface.

When these terms are individually examined, one realizes that there is a term which is fundamentally different from all the other terms. This term is the surface emission, usually hidden as a part of the net radiation. The surface emission term differs from other terms in that it is completely determinable by other terms. Other terms will be subject to changes by external conditions which are not expressly represented in this equation, such as cloud which influences global radiation, or wind which influences the turbulent fluxes. The surface emission term can be interpreted as the ultimate way in which the surface reacts thermally under given fluxes. Along this line of thought, the surface temperature can be expressed as:

$$
T=\left[\frac{(Q+q)(1-a)+L \downarrow+H+L_{\mathrm{v}} E+G+M}{\sigma}\right]^{\frac{1}{4}},
$$

or formulated in a differential manner:

$$
\begin{aligned}
& \frac{\mathrm{d} T}{\mathrm{~d} t}=\frac{1}{4 \sigma T^{3}} \\
& \times\left[\frac{\mathrm{d}(Q+q)(1-a)}{\mathrm{d} t}+\frac{\mathrm{d} L \downarrow}{\mathrm{d} t}+\frac{\mathrm{d} H}{\mathrm{~d} t}+L_{\mathrm{v}} \frac{\mathrm{d} E}{\mathrm{~d} t}+\frac{\mathrm{d} G}{\mathrm{~d} t}+\frac{\mathrm{d} M}{\mathrm{~d} t}\right] .
\end{aligned}
$$

Equation (2) illustrates how the surface temperature is formed. The contributions of each heat-flux term to the surface temperature formation are presented in Table 3 for various surfaces. One sees in the table that a significant difference is found not in net radiation but in an energy sink, and especially for tundra the small heat flux of melt is responsible for maintaining the higher temperature in the tundra region. Equation (3) expresses the influence of the changes in heat fluxes upon the temperature variability. The small diurnal amplitude of the temperature over the oceans and glaciers observed in summer is mainly due to the canceling effect of the diurnal change in the melt rate whose phase is shifted by $12 \mathrm{~h}$ in comparison with that for solar radiation. Equation (3) also explains how the same magnitude of the flux change on the righthand side causes temperature change to be larger in a colder climate. This aspect has a global relevance. It is generally known that the temperature change in the polar region is larger with almost all climate changes. The paleoclimatic case-studies for the last ice age maximum (CLIMAP Project Members, 1976), as well as global climate model experiments for the enhanced greenhouse effect (Manabe and Stouffer, 1994), produced this trend. The temperature sensitivity of the polar regions to a climate change is by now well established, and usually explained through the positive feedback relationship between the cryosphere and the temperature, which is certainly an important component. This process, however, is not the entire reason for the known high climatic sensitivity of the polar regions. The combination of the low temperature and how the thermal and electromagnetic energies are convertible to each other, that is, Planck's radiation law, is also a contributing basis for the high temperature sensitivity of the polar regions. The same magnitude of increase in the incoming longwave radiation as a result of the enhanced greenhouse effect causes almost twice as much temperature rise in the polar regions as in the tropics. Therefore, this type of climate sensitivity is certainly not exclusive to the polar regions, but should also apply to other regions of lower temperature, such as high altitudes.

Intensive microclimatological investigations on Axel Heiberg Island not only produced the scientific basis for understanding the tundra climate but reached far beyond the conventional boundaries of Arctic science. The research environment in the High Arctic Research Group of McGill University was truly interdisciplinary, though without the organization of a formal curriculum of interdisciplinary courses. Graduate students in different research areas worked side by side, learning from each other. The late Fritz Müller's dedication and enthusiasm made a deep impression on many of his students. The author of the present paper is certainly one who was inspired by this.

\section{ACKNOWLEDGEMENTS}

The present project was financed by the Swiss National Science Foundation through grant Nos. 20-29822690 and 203264911 and an ETH research grant, both for the Greenland Project. Financial support from the AVINA foundation for the Alliance for Global Sustainability, ETH/Massachusetts Institute of Technology/University of Tokyo, is gratefully acknowledged. 


\section{REFERENCES}

Ambach, W. 1963. Untersuchungen zum Energieumsatz in der Ablationszone des grönländischen Inlandeises (Camp IV-EGIG, $69^{\circ} 40^{\prime} 05^{\prime \prime} \mathrm{N}$, $49^{\circ} 37^{\prime} 58^{\prime \prime}$ W). Medd. Grønl., 174(4).

GLIMAP Project Members. 1976. The surface of the ice-age Earth. Science, 191 (4232), 1131-1137.

Hamilton, R. A. and G. Rollitt. 1957a. British North Greenland Expedition 1952-54. Climatological tables for the site of the expedition's base at Britannia Sø and the station on the inland-ice "Northice". Medd. Gronl., $158(2)$.

Hamilton, R. A. and G. Rollitt. 1957b. British North Greenland Expedition 1952-54. Meteorological observations at "North Ice", Greenland. Medd. Grønl., $158(3)$.

Havens, J. M. 1964. Meteorology and heat balance of the accumulation area, McGill Ice Cap, Canadian Arctic Archipelago — summer 1960 (Upper Ice Station I, 7941' N $90^{\circ} 27^{\prime}$ W, $1530 \mathrm{~m}$ ). Montréal, Que., McGill University. (Jacobsen-McGill Arctic Research Expedition 1959-1962. Axel Heiberg Island Research Reports. Meteorology 2.)

Jackson, C. I. 1959a. Coastal and inland weather contrasts in the Canadian Arctic. 7. Geophys. Res., 64(10), 1451-1455.

Jackson, C. I. 1959b. The meteorology of Lake Hazen, N.W.T., based on observations made during the International Geophysical Year 1957-58. Part I. Analysis of the observations. Ottawa, Ont., Department of National Defence. Defence Research Board. (Operation Hazen Report D. Phys R (G). Hazen 8.)

Loewe, F. 1935. Das Klima des grönländischen Inlandeises. In Köppen, W. and R. Geiger, eds. Handbuch der Klimatologie. Bd. 2, Teil K. Berlin, Verlag von Gebrüder Borntraeger, 67-101.

Manabe, S. and R. J. Stouffer. 1994. Multiple-century response of a coupled ocean atmosphere model to an increase of atmospheric carbon dioxide. 7. Climate, 7(1), 5-23.

Müller, F. and N. Roskin-Sharlin. 1967. A high Arctic climate study of Axel Heiberg Island, Canadian Arctic Archipelago - summer 1961. Part I. General meteorology. Montréal, Que., McGill University. (Axel Heiberg Island Research
Reports. Meteorology 3.)

Nansen, F. 1905. The Norwegian North Polar Expedition 1893-1896: scientific results.Vol.VI. Leipzig, Brockhaus.

Ohmura, A. 1981. Climate and energy balance on Arctic tundra, Axel Heiberg Island, Canadian Arctic Archipelago, spring and summer 1969, 1970 and 1972. Zürcher Geogr. Schr. 3.

Ohmura, A. 1982. Climate and energy balance on the Arctic tundra. F. Climatol., 2(1), 65-84.

Ohmura, A. and F. Müller. 1977. Die mesoklimatische Verteilung von Lufttemperatur und Niederschlag über der hocharktischen Tundra von Axel Heiberg Island, N.W.T., Kanada. Geogr. Helv., 32(4), 185-194.

Ohmura, A. and 6 others. 1994. Energy balance for the Greenland ice sheet by observation and model computation. International Association of Hydrological Sciences Publication 223 (Symposium at Yokohama 1993 - Snow and Ice Covers: Interactions with the Atmosphere and Ecosystems), 85-94.

Pugsley, W. I. 1970. The surface energy budget of central Canada. Montréal, Que, McGill University. Department of Meteorology. (Publication in Meteorology 96.)

Ratzki, E. 1960. Contribution to the climatology of Greenland. Paris, Expéditions Polaires Françaises. (Publ. No. 212.)

Simpson, G. C. 1919. British Antarctic Expedition, 1910-1913. Meteorology. Vol. 1. Discussion. Calcutta, Thacker, Spink and Co.

Sverdrup, H. U. 1933. The Norwegian North Polar Expedition with Maud, 1918 1925. Scientific results. Vol. III: Meteorology. Part II. Tables. Bergen, Geofysisk Institut.

Thompson, H. A. 1967. The climate of the Canadian Arctic. Toronto, Ont., Department of Transport. Meteorological Branch.

Vowinckel, E. and S. Orvig. 1964. Energy balance of the Arctic. V: The heat budget over the Arctic Ocean. Arch. Meteorol. Geophys. Bioklimatol., Ser. B, 14(3-4), 303-325.

World Meteorological Organization (WMO). 1971. Climatalogical norms (CLINO) for Climat and Climat ship stations. Geneva, World Meteorological Organization. (WMO Report 117.) 